\title{
Global Efforts towards Quality Education for All: Evidence and Reflections from an International and Comparative Educational Perspective
}

\author{
Vinayagum Chinapah*, Mikiko Cars, and Sarit Grinberg \\ Institute of International Education, Stockholm University, Stockholm, Sweden
}

\begin{abstract}
In the process of constructing post-2015 development global frameworks, education is increasingly seen globally to be a powerful tool for preparing students to enter labor market as well as to create a peaceful and sustainable society. International and comparative educational research conducted on the achievement of the EFA goals has clearly revealed that despite important efforts accomplished in many countries, there are still serious challenges in terms of the quality of education that is offered. The paper examines the extent to which a minimum Quality of Education for All (QEFA) can be reached through effective use and application of evidence-based international and comparative educational research. Global efforts to attain QEFA are examined by investigating major international surveys of learning outcomes. The case of Arab states demonstrates diverse socio economic and political contexts of each country and should be reflected in regional strategies to achieve QEFA. Evidence from data on national, regional and international assessments indicates that low achievement is globally widespread and stronger government intervention will be needed. This research demonstrates that the diversity of learning conditions and environment across and within countries should be carefully reflected into quality assurance by enhancing each individual's learning potentials.
\end{abstract}

Keywords: quality of education for all, international and comparative education, learning outcomes, EFA

\section{Introduction}

More than a decade has already passed since the beginning of this new millennium embracing a range of complexity in the politically, economically, and socio-culturally 
globalizing world. Technological innovation and advancement continue contributing to the world development to a great extent. However, the recent global financial crisis emanated from the financial systems of the developed world accelerated the rising poverty levels posing severe threats to progress in all areas of human development. Education and its development is more than ever at a very critical stage. Government budgets are under increasing pressure, and funding for education is vulnerable all around the world, while the critical importance of education in order to cope with the global crisis has been reemphasized from the perspective of the actualization of meaningful development of the individual and of the society at large, both a basic human right and for human capital investment. Tremendous efforts have been made especially since the World Conference on Education for All (WCEA) held in Jomtien, Thailand in 1990, then the World Forum of Education for All in Dakar in 2000. However, the Millennium Development Goals (MDGs) Reports by the United Nations (2005-2012) remind us of the continuously alarming situation of poverty, wide spread diseases especially the HIV-AIDS pandemic, the widening gap in the provision of basic human needs for food, shelter, sanitation and basic social services for the poor population of the world. Challenges of our time are further intensified and diversified due to rapid urbanization, the deteriorating situation regarding world peace and security, and the demand of knowledge societies.

Much of the comparative educational research conducted on the achievement of the EFA goals clearly revealed that despite important efforts accomplished in many countries, there are still serious challenges in terms of the quality of education that is offered. Despite the progress made towards the six EFA Goals set in Dakar at the World Forum of Education for All in April 2000, 61 million children of primary school age were out of school in 2010, the majority of whom (53\%) were girls mostly living in rural areas and city slums. Additionally, 71 million children of lower secondary school age were out of school in 2010 (UNESCO Institute of Statistics [UIS], 2012). Likewise, there are over 774 million adults deprived of their human rights to achieving basic literacy skills, and thus do not have the skills required to participate fully in society (Richmond, Robinson, \& Sachs-Israel, 2008). The marked disparities in levels of learning outcomes for the majority of learners which are determined by their very poor conditions of learning at home, at school and in the classroom on the one hand, and the unmet commitments of the development partners to basic education which currently stand far below the promised US\$11 billion yearly that are required to meet the 
EFA goals on the other, remain a daunting challenge (Chinapah, 2007). Recent assessments on students' learning achievement in a number of countries have shown that a sizeable percentage of children are only acquiring a fraction of the knowledge and skills they are expected to master at different grades after several years of completed education (Greaney \& Kellaghan, 2008). As an example, recent research reveals an alarming decline in performance levels among Swedish compulsory school pupils in mathematics, natural science and in reading comprehension (Swedish National Agency for Education, 2009).

To this effect, there is a growing interest today in the importance of cross-national comparisons of various aspects of the delivery of education, namely through curriculum, resources, governance, or teacher education and development. Trends in International Mathematics and Science Study (TIMSS) and Progress in International Reading Literacy Studies (PIRLS) are large-scale comprehensive international assessments that are conducted by the International Association for the Evaluation of Educational Achievement (IEA). TIMSS and PIRLS have played an important role in illustrating the potential value of such comparisons.

However, from a comparative research perspective across different nations, very little is known about what constitutes effective teaching and learning in different situational contexts, both between- and within- countries. More so, hardly any explanation is given from the empirical evidence which shows constantly over the decades as well as across nations, that children's differential learning outcomes are mostly accounted by their different socioeconomic and cultural backgrounds, by the different types of schools they attend, and by their school locations. Having relied only upon large-scale cross-sectional survey data, there is an urgent need today to use different but complementary research methods, for example "mixed methods research", to provide better understanding of individual differences in learning outcomes.

Quality will remain at the heart of education, which attracts learners, satisfies their basic learning needs, and enriches their lives and overall experiences of living. This paper therefore reflects what has been cogently argued about the success of meeting the EFA goals, namely the importance of working in partnership to ensure basic education of quality for all. This paper aims to examine and reflect on the extent to which a minimum quality of education for all can be reached through effective use and application of evidence-based educational research. In this endeavor, we will revisit the concept of quality education and move towards 
examining global efforts to improve quality education with reference to international surveys. This paper will then reflect on the case of Arab states, highlighting the efforts made in the region, demonstrating that diverse socio economic and political contexts should be reflected in regional strategies to achieve QEFA.

\section{Quality of Education and Learning Outcomes}

Research suggests that quality of education should ensure that children learn, and that what they learn is relevant to their needs (Caillods, Phillips, Poisson. \& Talbot, 2009). More insightfully, quality of education must be geared to enhancing each individual's potential and the full development of a learner's personality (Chinapah, 2003). In efforts of achieving quality of education, EFA Goal No.6 states:

Goal 6: Improving all aspects of the quality of education and ensuring excellence of all so that recognized and measurable learning outcomes are achieved by all, especially in literacy, numeracy and essential life skills. (UNESCO, 2000b: World Forum on

Education for All, Dakar, April 2000)

With regards to the implementation of the EFA Goal No.6, the Dakar Framework for Action established a holistic approach to quality of education. Regardless of gender, wealth, location, language or ethnic origin, quality education for all requires: 1) healthy, wellnourished and motivated students; 2) well-trained teachers and active learning techniques; 3 ) adequate facilities and learning materials; 4) a relevant curriculum that can be taught and learned in a local language and builds upon the knowledge and experience of teachers and learners; 5) an environment that not only encourages learning but is welcoming, gendersensitive, healthy and safe; 6) a clear definition and accurate assessment of learning outcomes, including knowledge, skills, attitudes and values; 7) participatory governance and management; and 8) respect for and engagement with local communities and cultures. ${ }^{1}$ Research suggests that there is a strong emphasis on the pursuit of education quality in current educational reforms in both local and international contexts and therefore continuous efforts shall be placed in order to re-examine what may constitute "quality in education" (Rotberg, 2010; Mukhopadhyay, 2009; UNESCO, 2005).

The definition of quality should take into account global and international influences. The quality movement emerged in the 1980's and 1990's in the context of broad structural changes and the introduction of new forms of public governance. The shift towards 
neoliberalism and the advance of globalization have made an impact on weakening state influence on the public sector and have pushed for competition and the race for development, steering the condition of education. The quality of education has become the focus in education discourse, visible by the increased emphasis on measuring outcomes and insistence on accountability and quality management at all levels (Nikel \& Lowe, 2010). The concept of quality education is contextual and value loaded (Penn, 2009) and there is no one definition, but many perspectives: 1) The human capital approach based on the idea that educational quality is a prerequisite for economic development (Soudien, 2012); 2) the human rights approach, which argues that quality and equity must work together to achieve a quality education system (Barrett, 2011); and 3) the perspective of all stakeholders having a voice and participating in defining what quality is (Soudien, 2012). In this view, definitions of quality reflect the values and beliefs, needs and agenda, influence and empowerment of various "stakeholder" groups having an interest in these services (Moss, 2009).

UNESCO (2010) defines quality education as one delivering quality education equitably and efficiently. The measure of the efficiency of an educational system is judged by its internal and external efficiency; internal efficiency measures the output and outcome of the education system while external efficiency measures the extent to which the skills and competencies acquired in school translate into private and social benefits (UIS, 2009). In the latest World Bank strategy document, Education Strategy 2020, it is emphasized that investments in quality education lead to rapid and more sustainable economic growth and development. Quality education, from the perspective of the World Bank, is about what kind of skills and competencies are acquired in schooling : "Growth, development, and poverty reduction depend on the knowledge and skills that people acquire, not the number of years they sit in the classroom" (The World Bank, 2011, p. vii). There is a consensus in policy documents and research that quality education should work to strengthen economic and human development.

Quality related debates tend to attach great significance to large scale testing which in turn leads to the focus on outcomes (Kumar, 2010). Outcomes are ever more so important in determining quality in education. Large scale tests such as the Programme of International Student Assessment (PISA) have influenced the debate on quality, as countries are constantly comparing themselves to others, and changing their policies and governance to reflect countries that are considered to have successful educational systems (the 'top performers') 
(Organization for Economic Co-operation and Development (OECD), 2012). Some form of comparison is required in order to make judgments of educational quality, or of progress in improving quality (Nikel \& Lowe, 2010).

National, regional and international assessments allow for the benchmarking of student performance against corresponding international standards. Learning outcomes in classrooms are often characterized by diversity with a wide range of abilities, which may include some students requiring special needs and supports. This indicates that standards and how to achieve them have to be tailored to every student. These concerns for equity and diversity can be seen as an alarm against external prescriptive standards, which are developed at national and international level. The significance of teachers' roles and abilities to engage themselves in interpreting and developing more detailed standards should be recognized (Hargreaves, Earl, Moor, \& Manning, 2001). In developing indicators to measure learning outcomes, these diversities at the individual level in the classroom should be carefully considered. Ultimately research findings on learning outcomes have significant potential in assisting countries in making informed decisions about interventions to improve educational quality and help policy makers monitor trends in the nature and quality of student learning (Kellaghan, Greaney, \& Murray, 2009). Focus on learning outcomes increases various stakeholders' attention on results, which may increase accountability based on performance. Much research has been conducted on surveys that measure improvement in learning outcomes. The richness, implications, strengths and weaknesses of these surveys, whether they are international, regional, national, cross-sectional or longitudinal, are constantly under review (Husén, 1989; Chinapah, $1983-2007^{2}$; Tuijnman \& Posthlethwaite, 1994; Kellaghan \& Grisay, 1995; UNESCO, 2000, 2007).

\section{Efforts towards Quality Education for All: Global Efforts to Improve Learning Outcomes}

At the World Conference for Education for All (WCEA), Dakar, March 2000, a significant importance was given to measuring improvement in learning outcomes. Besides providing equality of educational opportunities in terms of access, systems for measuring learning outcomes were strongly proposed to assist educational policy-making in the forms of development assistance, evaluation research, training and capacity-building, as well as advocacy support. The solid relationship between the six EFA Goals and the eight MDGs demonstrates coordination between global policy frameworks, which places education Journal of Education and Research, August 2013, Vol. 3, No. 2 
together with other important social and thematic sectors. Whereas the EFA Goal No. 2 encourages nations to strive for the provision of primary education of good quality, Goal No. 6 includes strategies to improve all aspects of education quality. However, a recent study from the EFA Global Monitoring Report (UNESCO, 2010) indicates that many countries are failing at achieving this level of quality; while not much action has been taken for those millions of children emerging from primary school each year without having acquired basic literacy and numeracy skills. Major observations in recent research are that while global discrepancy in access to school is narrowing in the effort of achieving EFA goals, discrepancy in educational quality remains enormous. Widening inequalities within and across countries is a serious concern. The results from TIMSS (2007) showed large gaps in learning achievement across countries. Average test scores for students from the top performing country are almost twice as high as for students from the bottom of the group. It should be noted that this survey did not include the poorest low-income countries, which would most likely have increased the discrepancy across and within countries even further than what was reported.

As to the global policy framework concerning literacy, the United Nations Literacy Decade was launched in 2003 to renew the commitment and efforts to improve literacy around the world, in the wider context of the Education for All (EFA goal No. 4). EFA goal No. 4 sets targets for literacy as "achieving a 50\% improvement in levels of adult literacy by 2015, especially for women, and equitable access to basic and continuing education for all adults." For countries with current literacy rates above 66\%, the goal for 2015 is universal literacy. Another framework concerning literacy is the Millennium Development Goals, which cover not merely education but also health, economic well-being, gender equality and other basic human needs or rights. However, research alarms that these do not account for levels of literacy skills that are fundamental in everyday life, nor do they reflect the different types of literacy skills needed in various situations, e.g. at work or at home. Global literacy measures are in critical need of improvement (UNESCO, 2005).

Another concern at the global level is the issue of equalizing opportunities. In order to achieve quality education for all, efforts should be made at various levels of the society to ensure that all learners regardless of their gender, socio-cultural, and linguistic background, achieve basic levels of learning needs. Chinapah (2010) points out that for assessment surveys to be useful in improving educational quality, it must be oriented towards inducing a 
response from practitioners in their roles as teachers, managers, or policy makers. Instruments, then, would have to be flexible and adaptable to the unique contexts of classrooms, schools and communities so as to uncover information that would be considered useable by the actors concerned.

A number of international cross-sectional surveys have been conducted measuring improvement in learning outcomes i.e. International Association for the Evaluation of Educational Achievement (IEA) and the International Assessment of Educational Progress (IEAP). IEA surveys have continued, among others, in the Trends in Mathematics and Science Studies (TIMSS) and Progress in Reading Literacy Study (PIRLS) which in many ways contributed to the recent OECD Programme for International Student Assessment (PISA). These surveys provide comparisons of learning outcomes between countries. TIMSS is an international assessment of the mathematics and science knowledge of fourth- and eighth-grade students around the world. TIMSS was developed in light of enabling participating nations to compare students' educational achievement across national borders. More than 60 countries and more than 600,000 students participated in TIMSS 2011. The IEA also conducts the Progress in International Reading Literacy Study (PIRLS). The objective of the PIRLS is to investigate the trends in reading achievement of fourth graders from more than 45 different countries. It is designed to measure students' reading literacy achievement, to provide a baseline for future studies of trends in achievement, and to gather information about students' home and school experiences in learning to read. PISA aims at testing literacy in three fields of competence: reading, mathematics, science. For PISA 2009, more than 470000 students from 65 countries had participated. The focus was on science but the assessment also included reading and mathematics and collected data on student, family and institutional factors that could help to explain differences in performance (OECD, 2010).

The WCEA brought a worldwide dimension to surveys that measure improvement in learning outcomes setting a concrete target ${ }^{3}$. The post Jomtien surveys of learning outcomes, with the exception of the international cross-sectional IEA surveys such as TIMSS or PISA, focused mainly on the realization of Article 4 of WCEA and the Jomtien target, aiming to strengthen their national and regional systems for continuous monitoring and assessment especially in the developing countries (Chinapah, 2010). These surveys include a) the joint UNESCO-UNICEF Monitoring Learning Achievement (MLA) ${ }^{4}$, b) the Latin American Laboratory for Assessment of Educational Quality (Laboratorio), c) the Programme for the Journal of Education and Research, August 2013, Vol. 3, No. 2 
Analysis of Educational Systems of the CONFEMEN Countries (PASEC), and d) the Southern Africa Consortium for Measuring Education Quality (SACMEQ).

Table 1

Some of the Major International Surveys of Learning Outcomes

\begin{tabular}{|c|c|c|c|}
\hline $\begin{array}{l}\text { Number } \\
\text { of } \\
\text { Countries }\end{array}$ & Surveys & $\begin{array}{l}\text { Grade and } \\
\text { Learning Areas }\end{array}$ & Participating Countries \\
\hline 72 & $\begin{array}{l}\text { Monitoring Learning } \\
\text { Achievement } \\
\text { (MLA) I \& II } \\
(1992-2004)\end{array}$ & $\begin{array}{l}\text { Grades } 4 \text { and } 5 \\
\text { Literacy, Numeracy } \\
\text { and Life Skills; } \\
\text { Grade } 8 \\
\text { Mathematics and } \\
\text { Science with Life } \\
\text { Skills. }\end{array}$ & $\begin{array}{l}\text { MLA I and II completed: } 49 \text { countries } \\
\text { Algeria, Azerbaijan, Botswana, Burkina Faso, } \\
\text { Burundi, Cameroon, China, Comoros, Croatia, } \\
\text { Ecuador, Gabon, Gambia, Jordan, Kazakhstan, } \\
\text { Kuwait, Kyrgyz Republic, Lebanon, Liberia, } \\
\text { Madagascar, Malawi, Maldives, Mali, Morocco, } \\
\text { Mauritania, Mauritius, Mongolia, Mozambique, } \\
\text { Nepal, Niger, Nigeria, Oman, Palestine, } \\
\text { Rodrigues (Mauritius), Rwanda, Sao Tome and } \\
\text { Principe, Senegal, Seychelles, Slovakia, South } \\
\text { Africa, Sri Lanka, Sudan, Tajikistan Tunisia, } \\
\text { Uganda, Uzbekistan, Yugoslavia, Zambia, } \\
\text { Zanzibar, Yemen. } \\
\text { MLA I and II ongoing: } 23 \text { countries } \\
\text { Armenia, Bahrain, Congo (Democratic } \\
\text { Republic), Equatorial Guinea, Eritrea, Ethiopia, } \\
\text { Ghana, Guinea, Guinea-Bissau, Haiti, Iraq, Ivory } \\
\text { Coast, Kenya, Lesotho, Namibia, Pakistan, } \\
\text { Qatar, Sierra Leone, Somalia, Swaziland, , Togo, } \\
\text { Turkmenistan, Tanzania (United Republic). }\end{array}$ \\
\hline
\end{tabular}

Latin American

Educational Quality

13

Assessment

Laboratory

Grades 3 and 4,

Language and

Argentina, Bolivia, Brazil, Chile, Colombia,

(Laboratorio) (1997)

Mathematics.

Costa Rica, Cuba, Honduras, Mexico, Paraguay,

Peru, Dominican Republic, Venezuela.

Programme of

Educational Systems

Grade 3,

Analysis (PASEC)

(1993-2000)

Mathematics and

Language.

Burkina Faso, Cameroon, Central African

Republic, Congo, Djibouti, Guinea, Ivory Coast, Madagascar, Mali, Niger, Senegal, Togo

Southern Africa

Consortium for

$15 \quad$ Monitoring

Educational Quality

(SACMEQ) III

Grade 6,

Reading Literacy, Math

Botswana, Kenya, Lesotho, Malawi, Mauritius, \& HIV/AIDS

Mozambique, Namibia, Seychelles, South

knowledge.

Africa, Swaziland, Tanzania (United Republic), Uganda, Zanzibar, Zambia, Zimbabwe.

(2007-2009)

Journal of Education and Research, August 2013, Vol. 3, No. 2 


\begin{tabular}{|c|c|c|c|}
\hline $\begin{array}{l}\text { Number } \\
\text { of } \\
\text { Countries }\end{array}$ & Surveys & $\begin{array}{l}\text { Grade and Learning } \\
\text { Areas }\end{array}$ & Participating Countries \\
\hline 48 & $\begin{array}{l}\text { Third International } \\
\text { Mathematics and } \\
\text { Science Survey } \\
\text { (TIMSS) (2011) }\end{array}$ & $\begin{array}{l}\text { Grades } 4 \text { and } 8 \text {, } \\
\text { Mathematics and } \\
\text { Science. }\end{array}$ & $\begin{array}{l}\text { Lithuania, Latvia, Romania, Ukraine, Sweden, } \\
\text { Bulgaria, Bosnia \&, Herzegovina, Hungary, } \\
\text { Norway, Denmark, Netherlands, Germany, } \\
\text { Scotland, England, El Salvador, United States, } \\
\text { Colombia, Czech Republic, Austria, Slovenia, } \\
\text { Italy, Morocco, Malta, Ghana, Israel, Jordan, } \\
\text { Serbia, Egypt, Turkey, Saudi Arabia, Qatar, } \\
\text { Thailand, Malaysia, Singapore, Australia, } \\
\text { Indonesia, New Zealand, Bahrain, Kuwait, } \\
\text { Oman, Yemen, Cyprus, Georgia, Kazakhstan, } \\
\text { Russian Federation, Armenia, Syria, Lebanon, } \\
\text { Hong Kong-China, Korea, Chinese Taipei, } \\
\text { Japan, Algeria, Botswana, Tunisia, Palestinian, } \\
\text { Slovak, Iran, South Africa, Portugal, Poland, } \\
\text { Spain, Croatia, Honduras, Azerbaijan, Belgium, } \\
\text { Chile }\end{array}$ \\
\hline $\begin{array}{l}65 \\
\text { Countries }\end{array}$ & $\begin{array}{l}\text { OECD / Programme } \\
\text { for International } \\
\text { Student Assessment } \\
\text { (PISA) (2009) }\end{array}$ & $\begin{array}{l}15 \text { year-olds } \\
\text { Reading, Mathematics } \\
\text { and Science. }\end{array}$ & $\begin{array}{l}\text { Australia, Korea, Argentina, Liechtenstein, } \\
\text { Albania, Austria, Luxembourg, Azerbaijan, } \\
\text { Lithuania, Shanghai-China, Belgium, Mexico, } \\
\text { Brazil, Macao-China, Dominican Republic, } \\
\text { Canada, Netherlands, Bulgaria, Montenegro, } \\
\text { Macedonia, Czech Republic, New Zealand, } \\
\text { Chile, Qatar, Moldova, Denmark, Norway, } \\
\text { Colombia, Romania, Panama, Finland, Poland, } \\
\text { Croatia, Russian Federation, Peru, France, } \\
\text { Portugal, Estonia, Serbia, Singapore, Germany, } \\
\text { Slovak Republic, Hong Kong-China, Slovenia, } \\
\text { Trinidad and Tobago, Greece, Spain, Indonesia, } \\
\text { Chinese Taipei, Hungary, Sweden, Israel, } \\
\text { Thailand, Iceland, Switzerland, Jordan Tunisia, } \\
\text { Ireland, Turkey, Kyrgyzstan, Uruguay, Italy, } \\
\text { United Kingdom, Latvia, Japan, United States, } \\
\text { Dubai, Kazakhstan }\end{array}$ \\
\hline
\end{tabular}

(Adapted from Chinapah, 2010)

An overview of such surveys during the period (1992-2009) in different regions of the world and by subject areas is provided in Table 1. EFA 2000 Assessment was implemented as part of the World Forum on Education for All (EFA) ${ }^{5}$ held in Dakar in 2000 in order to assess achievement of Jomtien's goal. The results from aforementioned surveys, mainly from the MLA project, were utilized to formulate EFA. The EFA 2000 assessment surveys of learning outcomes revealed that despite important efforts accomplished in many countries, there are still serious challenges to quality in education around the world. The inconsistent patterns of learner performance are observed across countries and between the three different learning areas. Teaching and learning outcomes are not only influenced by the specificity of a particular country, its teachers and learners, but equally by the specific characteristics of each 
and every learning area. The World Profile of Learning Outcomes: 1992-2002 Surveys illustrate the learning achievement profile of 72 countries in terms of literacy/language, numeracy/mathematics, and life skills/science, based on various international survey studies conducted. The results clearly show that very few countries have been successful since the Jomtien conference in guaranteeing, for example, 80 per cent of their cohort's success in mastery learning as defined by them following the target they chose from Jomtien. Mastery learning needs to be optimally used in order to guide intervention in such areas as assessment, curriculum reforms and improvement in teaching and learning. It can ensure quality learning through continuous monitoring and application of appropriate corrective measures and can assist in reaching the often-marginalized mass of learners who eventually drop out of educational systems.

\section{Efforts towards Quality Education: A Case of Arab States}

The Arab region is a remarkable case to look into, as it has recorded the fastest expansion in terms of average levels of educational attainment in the world, compared to other regions between 1990 and 2010 (Barro \& Lee, 2010). Educational traditions and change processes are linked to each country's specific broader societal, political and economic context. Quality of education should be carefully monitored in light of unique values, culture and history of each country (Rotberg, 2010). The exceedingly diverse socio-economic and political contexts of the Arab region signify that each country requires different strategies to achieve quality education for all. Many countries in the region have made significant investments in progressing and improving in teaching and learning conditions in order to enhance the quality of education, while other countries suffer from political instability leading to deprivation of basic human needs including education.

In terms of the conditions of teaching and learning, which is essential for learning quality, the results of the UNESCO-Beirut Quality Study from the national EFA Mid-Term Review 2008 reported in details the significant improvement in many member states. During the period of mid-term review (2000-2007), efforts have been made to reduce class density as well as to construct basic school infrastructures, e.g. school buildings and furniture, clean drinking water (Jordan, UAE, Bahrain, Saudi Arabia, Oman, Qatar). Furthermore, learning resource centers equipped with ICT facilities, multi-purpose halls, libraries, air conditioning units in all rooms were provided by Oman and Qatar. However, significant differences 
between countries in terms of provision of basic school needs and infrastructure for teaching and learning have been emphasized.

Another essential element in quality education is adequate curriculum and quality textbooks. The Arab Bureau for Education in the Gulf States (ABEGS) has played a central role in the curriculum reform in the region, to modernize and update the skills, attitudes and competencies in the context of globalization. Textbooks have been revised in order to promote a learner-centered pedagogy incorporating critical thinking and problem-solving skills. However, issues such as ecological environment, population, and gender still need to be addressed further (UNESCO-Beirut, 2007).

Teachers' training remains the most important policy towards the improvement of the quality of education in all countries in the region. Morocco demonstrates a good example of consistent growth in pre-service and in-service program for teachers and educational personnel since 2001, in the context of its educational decentralization policy. The Morocco National EFA Mid-Term Review Report (2007) reports that the objectives of pre-service programs are revised and training institutions have been re-organized in order to improve the quality of teachers' training. Teacher recruitment procedures have been revised to decentralize to the regional level, aligned with university training programs. Also, a standard test of education and training are introduced in order to control the quality. However, the range of teachers having required qualifications differs between countries in the region. UNESCO-Beirut 2007 Quality Study shows that the range is between 90-100 per cent in 7 countries (Emirates, Saudi Arabia, Algeria, Oman, Qatar, Morocco, and Mauritania), 88.9 per cent in Kuwait and around 70 per cent in 4 countries (Jordan, Bahrain, Iraq, and Egypt). In countries in conflict or post-conflict situations, percentages of qualified teachers are worse. The tendency is the same in rural areas. Also, in countries like Lebanon, the percentage of qualified teachers is low due to low remuneration and a large share of private sector education (UNESCO-Beirut, 2007).

The total public expenditure on education as a percentage of total government expenditure indicates a nation's political will and priority to invest in human resources development, in relation to other sectors. Among the countries with relevant data, a number of countries allocate significant amount of national budget on education: Oman (31.1\%), Morocco (25. 7 \%), United Arab Emirates (23.4\%), Tunisia (22.4\%), Algeria (20.3\%), 
Saudi Arabia (19.3\%), followed by Syria (16.7\%), Yemen (16.0\%), Mauritania (15.6\%), Kuwait (12.9\%), Egypt (11.9\%), and Bahrain (11.7\%), (Data from United Nations Statistics Division, 2008). It should also be noted that public expenditure on education is only a part of the efforts, especially with regard to basic education. In countries like Sudan, Morocco, and Mauritania, it is observed that other actors' e.g. local communities, private associations, NGOs and religious groups, support in the provision of basic education facilities are noted as well as families’ own financial contributions (UNESCO-Beirut, 2008).

The UNESS 2007 comprehensive studies in-line with the UN reform at the country level, which was successfully participated by 14 out of 19 Arab States in the region, could be seen as an example of local assessment of the quality of education at the national level, empowering and strengthening capacities at the local level aligning with the global agenda. Critical examination of different surveys of learning achievement in related to EFA Goal No. 6 was made using the results from international surveys such as the MLA and the TIMSS. Ten Arab countries participated in TIMSS 2003, this number rose to 14 countries in addition to the Emirate of Dubai in TIMSS 2007. A total of 16 Arab countries participated in TIMSS 2011. The high level of participation of the Arab States in TIMSS, PIRLS and PISA indicates high commitment to improve educational quality in the region.

Results of the TIMSS survey (2007) indicated remarkable disparities in learning among Arab states, pointing out for example in Qatar, Saudi Arabia, Algeria, Egypt and Morocco, more than half of the students register below the lowest score threshold. This low educational achievement in Arab states is attributed to various factors including reduced teaching time, the shortage of textbooks, and the weakened capacity to apply learning materials to an effective teaching-learning process. These results imply serious policy challenge for Arab states due to the fact that not having effectively been able to translate investment in education into improved skills, employment creation and economic growth (UNESCO, 2010; UNDP \& Mohammed bin Rashid Al Maktoum Foundation, 2012).

In order to confront with the dual challenge of expanding access to education and improving student learning, national assessment surveys play a significant role. Many countries in the Arab region have been conducting regular monitoring and evaluation at different levels. For example, Kuwait employs innovative evaluation method known as "Achievement file", which is in line with the overall educational strategy of the state 
(2005/2025). The file serves as continuous formative and constructive assessment to improve learning quality, in response to the learners' aspirations to improve their performance by recording students' learning activities. Students participate in their own evaluation to promote self-assessment skill, involving also parents and teachers. Another good example is Qatar's Independent Schools, which are based on self-management of school affairs including the school curricula, the teaching and evaluation methods, with active involvement of parents and the wider society. The MLA Project served as an important capacity strengthening tool developing a "Culture of Evaluation and Monitoring of Quality Education" in every county, by supporting to identify nationally defined tests of learning outcomes. Eleven countries in the region, namely Algeria, Jordan, Kuwait, Lebanon, Mauritania, Morocco, Oman, Palestinian Autonomous Territories, Sudan, Tunisia and Yemen, successfully participated in the MLA project. The analyses of the MLA surveys, which were carried out for the EFA 2000 Assessment in the Arab region, found that with few exceptions, girls did better than boys in all three areas tested (literacy, numeracy and life skills). However, the major source for disparities in learning outcomes was due to the school location (urban/rural) and school type (private/public) (Chinapah, 2010). The empirical findings from the MLA surveys for EFA Goal No. 6 in the Arab region confirmed that high priority has to be given to in-depth evaluations of the factors influencing students' learning outcomes. Improving the quality of education can never be realized by bringing about the improvement at the school level or within the system alone, but should be expanded to include the family context.

Tremendous political commitment towards the achievement of the EFA goals acknowledged, issues and challenges towards attaining quality education in the Arab states are also identified. Discrepancy of income levels among the member countries poses uneven performance and achievement; low income countries such as Djibouti, Mauritania and Yemen, as well as post-conflict situation countries such as Iraq, Lebanon, the Palestinian Autonomous Territories and Sudan continue to face difficulty. The EFA Regional Report for the Arab States 2011 (UNESCO-Beirut, 2011) reports the following issues and challenges towards the common goals: 1) need to effectively harmonize the EFA coordination mechanism among partners at the national and international levels; 2) need to reach marginalized populations, especially regarding the quality of early childhood care and education (ECCE); 3) unbalanced and slow trends in primary education delivery; 4) lack of quality standard in education system which reflect local needs; 5) need to stimulate creativity 
and interest in learning which can adapt to changes in global context; 6) demographic challenges: high fertility rate in poor rural areas and high illiteracy rate; 7) increasing number of displaced and refugee children; 8) geographical and urban-rural inequality; 9) need to develop educational opportunities for children with special needs; 10) need to develop nonformal education program to support disadvantaged learners in context of poverty, child labor, HIV/AIDS, remote geographical location, ethnicity, civil conflict, natural disasters, etc. The Arab region still contains 6 million children out of school and 60 million adult illiterates and is working towards attaining the goal of Quality Education for All, in line with Global framework, maintaining national identities.

\section{Quality Education for All - Still Miles Ahead}

Empirical studies have demonstrated that high quality schooling improves national economic potential as well as social benefits. This paper depicts only a small picture of the constant tremendous efforts made at the global and local levels in the effort to achieve universal quality education.

Since the EFA conference in Jomtien in 1990, two decades have passed. The main observation is that while much has been achieved during these twenty years, still a lot remains to be done in narrowing disparities within and across countries. The TIMSS 2007 found that on average students in countries such as Ghana, Indonesia and Morocco performed below the poorest-performing students in countries such as Japan and the Republic of Korea. Another international survey by PISA in 2006 demonstrated that while performance differences between students and schools from varying socio-economic contexts are found in many countries (e.g. Germany, Bulgaria, Czech Republic, Austria, Hungary, the Netherlands, Belgium, Japan, Italy, Slovenia, Argentina, and Chile), in other countries (e.g. Finland, Iceland, Norway, followed by Sweden, Poland, Spain, Denmark, Ireland, Latvia and Estonia) school differences played only a minor part in performance variation. This evidence implies the significance of providing learning opportunities for all students irrespective of their socioeconomic background. The Swedish education system which is highly decentralized, for example, pursues equity in the society including educational access to all and further promotes the idea that schools should help in minimizing the influence of the home (Swedish National Agency for Education, 2009). In Mauritius, elimination of disparities in learning outcomes stemming out from socio-economic background has been identified as a challenge more than two decades ago. Efforts have been made to significantly improve the learning 
outcomes; however, urban-rural disparities as well as performance variation based on types of school within learning areas are reported as further challenges. In Bangladesh, where national development objectives and plans regard education as a strategic tool for poverty reduction and human development, inequity and large-scale deprivation of access and participation in the primary education system has been a serious concern. In South Africa despite numerous educational reforms, in the context of social and political transition, poor level of primary school learning achievement is reported. All these national examples demonstrate that each country is contextualized with their unique political, social and economic priorities, which developed over time and this implies that definition of "quality" varies tremendously (see more discussions in Chinapah, 2010).

Empirical research shows that there is no single best way to improve learning outcomes, as learning environment conditions differ tremendously across and within countries. However, research also indicates that an improved learning environment is one of the most important requirements for sustainable progress towards better quality in education, which includes the physical school infrastructure, the learning process and the interaction between students and teachers (UNESCO, 2010).

The impressive efforts from regional, national, international, to global level in reforming education systems has resulted in an increasing awareness of a number of challenges in attaining quality education. However, evidence from data on national and international assessments indicates that in too many countries, students are yet not mastering basic skills. Low achievement is widespread and there is an urgent need to effectively harmonize the mechanism among multiple partners at the national and international levels to attain QEFA. Quality education must reach to a large mass of marginalized populations, addressing geographical and urban-rural inequality taking gender disparities and learners with disadvantaged socio-economic, cultural and individual backgrounds into consideration.

\section{Notes}

${ }^{1}$ See Chinapah (Ed.) (2006).

${ }^{2}$ These surveys by Chinapah include: Performance and Participation in Primary Schooling (1983); Differential Access to Primary Schooling: Can Education Promote Equality in a Multi-cultural Society? (1987); Evaluation and Follow-up of Educational Policies, Plans and Reforms (1991); Monitoring and Surveying Learning Achievements: A Status Report

Journal of Education and Research, August 2013, Vol. 3, No. 2 
(1992); Monitoring Learning Achievement -Towards Capacity Building (1995); After Jomtien: UNESCO's current policy on assessment (1996); Handbook on Monitoring Learning Achievement: Towards Capacity Building (1997); With Africa for Africa Towards Quality Education for All (1999); Education for All. Monitoring Learning Achievement. EFA 2000 Assessment Surveys (2000); Monitoring Learning Achievement (MLA) in Africa (2005).

${ }^{3}$ It spelled out a special target, the "improvement in learning achievement such that an agreed percentage of an appropriate age cohort (e.g. 80 percent of 14 year-olds) attains or surpasses a defined level of necessary learning achievement" (UNESCO, 1990, p.53)

${ }^{4}$ The joint UNESCO-UNICEF MLA Project (1992-2004) was one of the largest in scale, which covered all regions of the world (72 countries) at different grade levels $(4,5,8)$ and in different subject areas (language, mathematics, sciences and life skills).

${ }^{5}$ Status and Trends: Assessing Learning Achievement, (UNESCO, 2000a) presents the results from Dakar conference.

\section{References}

Barrett, A. M. (2011). A millennium learning goal for education post-2015: A question of outcomes or processes. Comparative Education, 47(1), 119-133.

Barro, R, J., \& Lee, J. W. (2010). A new data set of educational attainment in the world, 1950-2010. (Working Paper No. 15902). Massachusetts: National Bureau of Economic Research.

Caillods, F., Phillips, M., Poisson, M., \& Talbot, C. (2009). Overcoming the Obstacles to EFA. Research Papers IIEP. Paris: IIEP/UNESCO.

Chinapah, V. (2003). Importance of networking and capacity-building for the promotion of quality education in Europe. In Quality education in European context and the Dakar follow-up: Proceedings of the international seminar (pp. 11-15). Slovakia: Constantine the Philosopher University in Nitra.

Chinapah, V. (2006). Review and stocktaking of EFA progress (RASEP): Programme proposal (Education Sector). Paris: UNESCO.

Chinapah, V. (2007). Educational surveys: The world perspectives - Working document for the intensive capacity-building workshop. Amman, Jordan: UNESCO. 
Chinapah, V. (2010). Education for All (EFA) - A critical review. In H. Daun \& G.

Strömqvist (Eds.), Education and development in the context of globalization (pp. 2557). Huntington, NY: Nova Science Publishers.

Greaney, V., \& Kellaghan, T. (2008). Assessing national achievement levels in education. Washington, DC: World Bank.

Hargreaves, A., Earl, L., Moor, S., \& Manning, S. (2001). Learning to change: Teaching beyond subjects and standards. San Francisco: Jossey-Bass.

Husén, T. (1989). Educational research at the crossroads? An exercise in self-criticism. Prospects, XIX(3), 169-190.

Kellaghan, T., \& Grisay, A. (1995). International comparisons of student achievement: Problems and prospects. In OECD, Measuring what students learn (pp.41-61). Paris: Author.

Kellaghan, T., Greaney, V., \& Murray, T. S. (2009). Using the results of a national assessment of educational achievement (5). Washington DC: World Bank.

Kumar, K. (2010). Quality in education: Competing concepts. Education Dialogue, 7(1), 718.

Moss, P. (2009). Defining quality: Values, stakeholders and processes. In Rethinking Welfare (pp. 1-9). London: Sage.

Mukhopadhyay, M. (Ed.). (2009). Quality school education for all. New Delhi: Educational Technology and Management Academy.

Nikel, J., \& Lowe, J. (2010). Talking of fabric: A multi-dimensional model of quality in education. Compare: A Journal of International and Comparative Education, 40(5), 589605.

OECD. (2010). PISA 2009 at a glance. OECD Publishing.

OECD. (2012). Education today 2013: The OECD perspective. OECD Publishing.

Penn, H. (2009). Working in conflict: Developing a dynamic model of quality. In Rethinking Welfare (pp. 10-27). London: Sage.

Richmond, M., Robinson, C., \& Sachs-Israel, M. (Eds.). The global literacy challenge: A profile of youth and adult literacy at the mid-point of the United Nations literacy decade 2003-2012. Paris: UNESCO.

Rotberg, I. C. (Ed.). (2010). Balancing change and tradition in global education reform (2nd ed.). Plymouth, UK: Rowman \& Littlefield Education. 
Soudien, C. (2012). Quality's Horizons. In S. J. Klees, J. Samoff, \& N. P. Stromquist (Eds.), The World Bank and education: Critiques and alternatives (pp. 95-107). The Netherlands: Sense Publishers.

Southern Africa Consortium for Measuring Education Quality (SACMEQ). (1998). The quality of education: Some policy suggestions based on a survey of schools. Paris: IIEP, UNESCO.

Swedish National Agency for Education (Skolverket). (2009). What influences Educational achievement in Swedish schools? - A systematic review and summary analysis. Stockholm: Swedish National Agency for Education.

Tuijnman, A. C., \& Postlethwaite, T. N. (1994). Monitoring the standards of education. UK: Pergamon.

UNDP. (2003). Arab TIMSS 2003 regional report executive summary. Retrieved from http://www.arabtimss-undp.org/default.aspx?id=1baselnime\&tar=default.aspx

UNDP \& Mohammed bin Rashid Al Maktoum Foundation. (2012). Arab knowledge. Report 2010/2011: Preparing future generations for the knowledge society. Dubai: Al Ghurair.

UNESCO. (2000a). Status and trends. Assessing learning achievement. Paris: UNESCO.

UNESCO. (2000b). The Dakar framework for action. Paris: UNESCO.

UNESCO. (2005). EFA global monitoring report 2006. Education for all: Literacy for life. Paris: UNESCO.

UNESCO. (2007). Education for all global monitoring report 2008. Education for all by 2015: Will we make it? Paris: UNESCO.

UNESCO. (2010). EFA global monitoring report 2010. Reaching the marginalized. Paris: UNESCO.

UNESCO-Beirut. (2007). Office reports, 2005-2007. Beirut: UNESCO Regional Bureau.

UNESCO-Beirut. (2008). Quality education. In Sharpening our tools. Education for all midterm review for the Arab states 2008 (Chap. 2, pp. 50-70). Beirut: UNESCO Regional Bureau.

UNESCO-Beirut. (2011). EFA regional report for the Arab states 2011. Beirut: UNESCO Regional Bureau.

UNESCO Institute of Statistics. (UIS). (2009). Education indicators: Technical guidelines. Montreal: UNESCO, UIS. 
UNESCO Institute of Statistics (UIS). (2012). Reaching out-of-school children is crucial for development. UIS Fact Sheet, No. 18.

United Nations. (2007). The millennium development goals report 2007. New York: Author.

World Bank. (2011). Education strategy 2020: Learning for all: Investing in people's knowledge and skills to promote development. Washington DC: World Bank. 